\title{
Las Chicas Águila. El uso sexista de la mujer en la publicidad colombiana
}

\section{The Girls Eagle. The sexist use of women in Colombian advertising}

TIPO DE TRABAJO: Comunicación

PALABRAS CLAVES

Mujer, imagen, estereotipo, publicidad, patriarcado, sexismo.

KEY WORDS

Woman, image, stereotype, advertising, patriarchy, sexism.

RESUMEN

La figura femenina erotizada y expuesta, día a día, en la publicidad parece rememorar la regla o característica del escándalo visual, en cuya psicología del consumo no pueden faltar mujeres que llamen al deseo sexual a partir de la función de implicación de la imagen con el observador, que antecede a cualquier cualidad del producto enunciado. En este sentido, el objetivo de este artículo es analizar a partir de la campaña publicitaria Las chicas Águila, que se basa en la imagen de mujeres jóvenes en bikini y ajustadas camisetas de fútbol, hipersexualizadas y en actitudes de festejo y celebración- cómo han sido utilizados los estereotipos sexistas sobre la mujer para vender cerveza en Colombia. En dicha campaña se observa que las mujeres son presentadas como imágenes-objetos o fetiches de belleza para ser contempladas y deseadas, hecho que es aceptado en el cotidiano y ha sido normalizado, aunque sea un mecanismo de violencia simbólica y de cosificación de la mujer. El método utilizado es el análisis de las imágenes de la campaña publicitaria a partir de algunos elementos de semiótica en la publicidad, la referencia a especialistas en el tema de los estereotipos femeninos y el análisis en el contexto sociocultural de Colombia.

\section{ABSTRACT}

The eroticized and exposed female figure, day by day, in advertising seems to recall the rule or characteristic of the visual scandal, in whose psychology of consumption there can be no shortage of women who call for sexual desire from the function of involvement of the image with the viewer, which precedes any quality of the product enunciated. In this sense, the objective of this article is to analyze, based on the advertising campaign 'Las Chicas Águila', which is focused on the image of young women in bikinis and tight soccer shirts, hypersexualized, party and celebration attitudes, how sexist stereotypes about women have been used to sell beer in Colombia. In this campaign it is observed that women are presented as images-objects or fetishes of beauty to be contemplated and desired. A fact that is accepted in everyday life and has been normalized, although it is a mechanism of symbolic violence and reification of women. The method used is the analysis of the images of the advertising campaign that was based on some elements of semiotics in advertising, the reference of specialists in the subject of female stereotypes, and the analysis in the socio-cultural context of Colombia. 
Toloza Hernández, José Germán

Las Chicas Águila. El uso sexista de la mujer en la publicidad colombiana

IV Congreso INTERNACIONAL DE INVESTIGACIÓN EN ARTES VISUALES ANIAV 2019

IMAGEN [N] VISIBLE]

http://dx.doi.org/10.4995/ANIAV.2019.9019

\section{INTRODUCCIÓN}

El que ama las cosas bellas, ¿qué desea? -Que lleguen a ser suyas, dije yo.

Sócrates

Desde mediados de los años 90 la cervecería colombiana Bavaria ha publicitado la venta de cerveza Águila con un grupo de modelos jóvenes, bellas y delgadas, que, en traje de baño de dos piezas, o con pequeñas camisetas de la selección masculina de fútbol, promueven el consumo de cerveza. En las imágenes de afiches, almanaques y en la internet, las modelos aparentan vivir en una fiesta perpetua que transcurre en playas paradisiacas. Tras su éxito, principalmente entre el público masculino, la campaña se reconoce como el fenómeno de Las Chicas Águila, y tiene claros matices utilitaristas de la figura femenina al tiempo que se convierte en replicador de los estereotipos femeninos, en un contexto cultural propicio, como caldo de cultivo para los machismos. Esto, frente a un escenario global de pronunciamientos críticos sobre la cosificación de la mujer, y en un momento en que voces feministas exigen respeto, igualdad de derechos y lucha contra la violencia de género.

La relación histórica de la mujer con la publicidad está ligada a visiones heredadas de las representaciones artísticas en el arte sobre la figura femenina, como las Venus, y también de las adaptaciones de las figuras judeocristianas como Lilith y Eva. Al mismo tiempo, el posicionamiento de estas imágenes está determinado por los niveles de efectividad sobre nuestra capacidad y disposición a apasionarnos ante sus encantos. Según Puelles (2009), "Cuando Venus se convierte en imagen irresistible y amada, Eros se nos mete en la carne tomándonos el cuerpo, "apasionándonos". [...] El cuerpo tentado está tocado y tenso. Quien está tentado sufre en su cuerpo la pasión introducida por el deseo".

Las mujeres de la publicidad de la cerveza Águila se presentan como jóvenes esplendorosas y deseables, en paisajes paradisiacos, que, generalmente, miran fijamente al espectador. "Todo ocurre como si la publicidad pretendiera utilizar el interés artístico de las imágenes para atraer la atención y concibiera el anuncio como una obra de arte hecha por un artista al servicio de una mercancía" (Peninou, 1976).

En este contexto, según Peninou (1976), la publicidad cumple la función de centrar el interés, no ya en el producto sino en un valor o en un estilo de vida, que en el caso de Las Chicas Águila vendría a ser una especie de tierra prometida para el placer. Su belleza, dada la diversidad racial que convoca, pareciera ofrecerse para todos los gustos, con cánones distantes de la vida real, ayudados por el diseño y la manipulación digital:

[...] La publicidad tiene la obligación de transmitir algo, y ese algo no es tanto un producto o un objeto, como suele afirmarse, como un valor a significar para sus fines: no solo un jabón de tocador sino su dulzura sin igual; no solo el cigarrillo, sino su incomparable aroma...

Las imágenes estereotipadas de Las Chicas Águila son efectivas debido a su belleza, ligada a procesos de reacondicionamiento y apropiación que la publicidad ha sabido reinterpretar desde la generosidad de imágenes heredadas por la historia del arte.

En este artículo pretendemos analizar cómo, en la cultura del espectáculo contemporáneo del consumo, la estetización y la hípererotización de la figura femenina son un gran negocio que remonta cualquier intento reflexivo sobre la ética de respeto por los efectos negativos que sufren las mujeres reales, en el cotidiano.

Según Rodríguez (2009):

[...] Las mujeres suelen ser presentadas como imágenes para ser vistas, adoradas y deseadas, y los hombres como los que suelen ver esas imágenes y las poseen". (...) Esta visión masculina de ver el mundo es definida como la norma universal. La mujer se convierte en el objeto de la mirada, tanto del personaje masculino como del espectador, que deviene en espectáculo o fetiche, pues ella se convierte en fetiche de belleza. La mujer se convierte en un objeto que se considera a sí misma un objeto de contemplación. (p.5) 


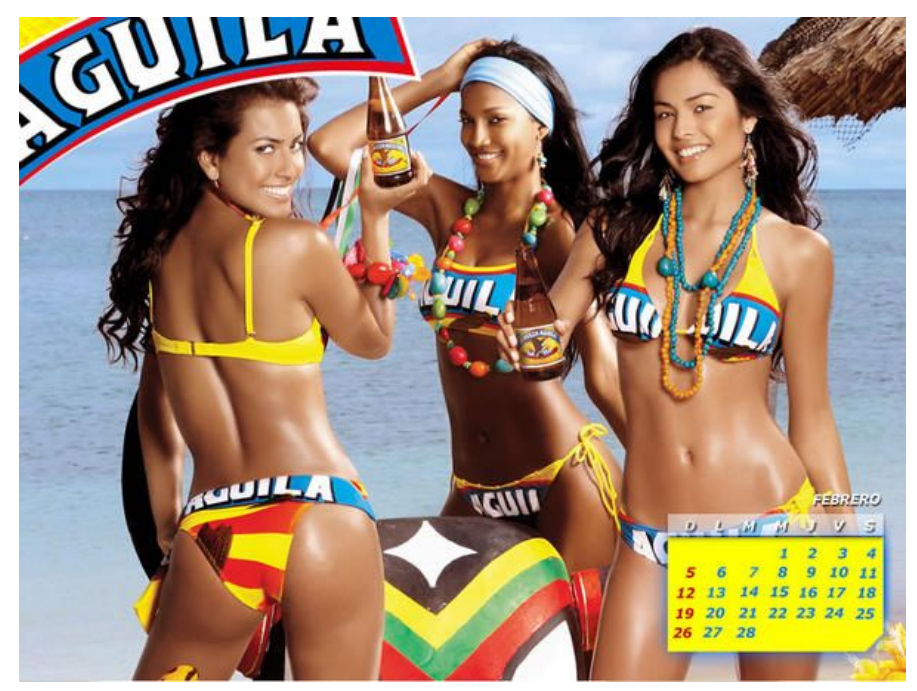

Figura 1. Publicidad. "Calendarios de Las Chicas Águila”, Cervecería Bavaria. "Fuente: https://www.taringa.net/+imagenes/las-chicas-aguila-colombia i3efr"

La hipótesis de este artículo se basa en la posibilidad de contribuir a generar una visión crítica e interpretativa de la publicidad que hace uso de la figura femenina, para que pueda ser releída en el contexto de una cultura más responsable y respetuosa con los otros, en concreto, de las mujeres, en el agudo ambiente que genera la violencia de género en la actualidad.

\section{DESARROLLO}

\section{Las Chicas Águila}

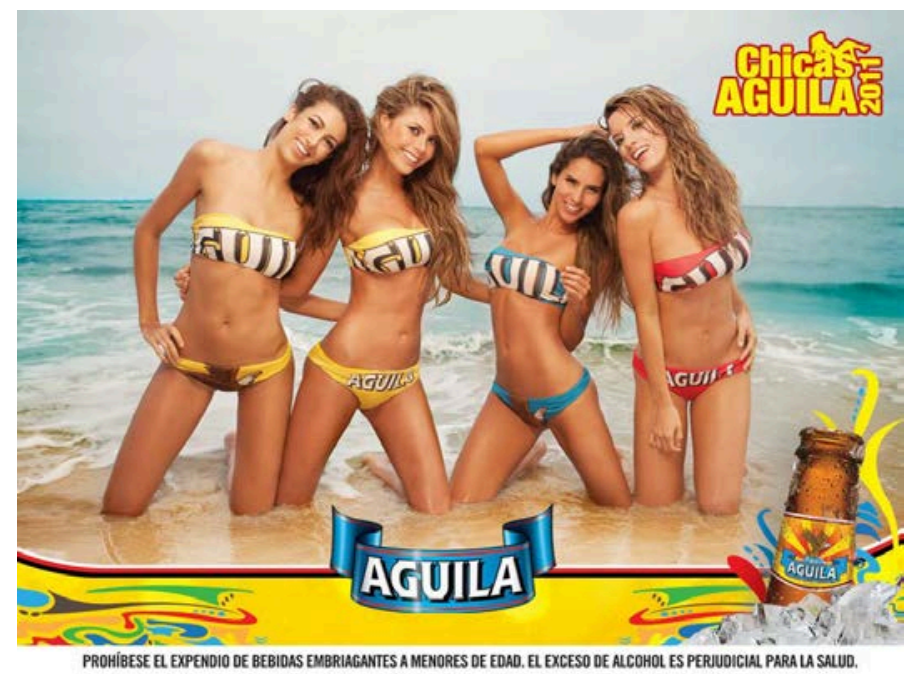

Figura 2. Publicidad. “Chicas Águila 2011”, Cervecería Bavaria, 2011. “Fuente: http://cerveza.me/74210/Chicas-de-Aguila-2011?page=1”

Las Chicas Águila son un grupo de mujeres elegidas siguiendo el formato de un reinado de belleza dirigido a la campaña publicitaria de cerveza, que se ha caracterizado, desde los 90, por incluir imágenes de modelos en bikini o en pequeñas camisetas de fútbol, en ambos casos con el estampado de la marca Águila. Los colores de la publicidad concuerdan con los de la bandera colombiana, amarillo, azul y rojo; en consecuencia, tienen una intención nacionalista y populista, promoviendo el amor patrio asociado al fútbol y la rumba cervecera. Suelen estar en escenarios como la playa, billares o campos de fútbol, lugares que se asocian con la diversión masculina.

De las poses de las modelos emana energía, alegría y una disposición al juego y la celebración, en un entorno que pone en perspectiva el cielo y el mar, y, en primer plano, la arena sobre la que ellas juguetean disfrutando de una botella de cerveza. La belleza de la imagen, que sugiere un arduo trabajo estético de diseño y psicología publicitaria, se corresponde con la potencia para sugerir un desear ver y estar implicado en la escena, como voyerista o partícipe imaginario. La cuidadosa carga misógina se asegura de que las 
Toloza Hernández, José Germán

Las Chicas Águila. El uso sexista de la mujer en la publicidad colombiana

IV Congreso INTERNACIONAL DE INVESTIGACIÓN EN ARTES VISUALES ANIAV 2019 IMAGEN [N] VISIBLE]

http://dx.doi.org/10.4995/ANIAV.2019.9019

imágenes no pasen desapercibidas, ya sea en las tiendas donde concurren los hombres a beber cerveza en grupo, o en los talleres de mecánica automotriz, donde habrá suficiente tiempo de espera.

La trampa de seducción utilizada, centrada en el placer de espiar y el derecho de macho a mirar sin contemplación, funciona. Por ello se le invierte un cuantioso capital, pues la idiosincrasia del hombre colombiano es receptiva a esta empresa.

\section{Latencia participativa}

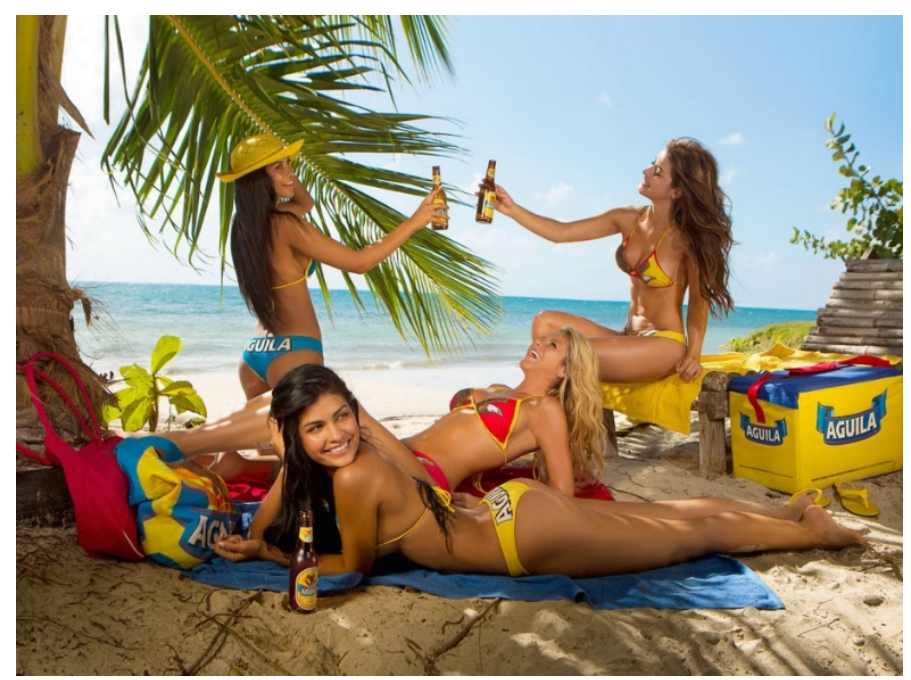

Figura 3. Publicidad. "Grupo de Chicas Águila”, Cervecería Bavaria. “Fuente: https://www.pinterest.es/pin/646196246503202846/”

"Los mensajes de implicación hacen de la proposición publicitaria una propuesta a terceros. Transforma al destinatario en participante de un intercambio" (Peninou, 1976).

En algunos afiches, en lo que parecen ser rituales celebrativos grupales que hacen alusión al harén, las mujeres viven la rumba, el carnaval o la celebración del gol, acciones donde supuestamente las miradas masculinas desean entrar a contemplar o a apropiarse de la belleza ofrecida para satisfacer el placer voyerista. Este deseo latente de participación es algo que podemos rememorar en la relación establecida entre las venus renacentistas reclinadas y el espectador varón a quien va dirigida la mirada y toda la escena expuesta. Desde ese ángulo, los dúos o tríos de chicas estarán dispuestos para ser completados por el espectador; en otros casos, una chica solitaria en los arreboles del Caribe también parece esperar la compañía del espectador.

De estas cuantificaciones de cuerpos (solos, tríos y harems) puestos en escena, llama la atención el solo de la chica que sostiene una botella en la mano o que la lleva a sus labios. De esa imagen se desprende una tipología llamada por Campos (2016) la mujer fálica.

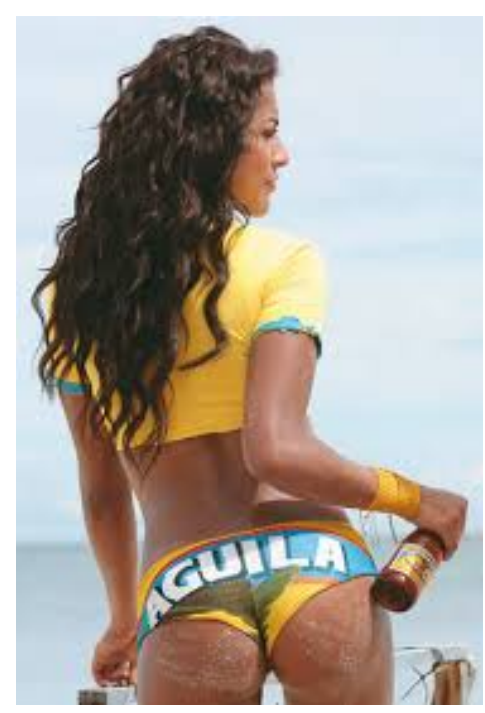

ANIAV Asociación Nacional de Investigación en Artes Visuales 
Toloza Hernández, José Germán

Las Chicas Águila. El uso sexista de la mujer en la publicidad colombiana

IV Congreso INTERNACIONAL DE INVESTIGACIÓN EN ARTES VISUALES ANIAV 2019 IMAGEN [N] VISIBLE]

http://dx.doi.org/10.4995/ANIAV.2019.9019

Figura 4. "Chica Águila con botella", Publicidad Cervecería Bavaria. "Fuente: http://www.bebideria.com.br/2014/07/as-10-cervejas-mais-valiosas-domundo.html"

[...] mujer fálica, esplendorosa en su omnipotencia, a veces amenazadora y castradora, que en muchos casos, exhibe un objeto que le fue acoplado, es decir, el objeto publicitario. Este ocupa el lugar de un falo imaginario, esencia de los más recónditos deseos infantiles del niño: el fetiche.

Según la investigadora, esa mujer esplendorosa es tan amenazadora y castradora, porque ciega y eclipsa el fluir del deseo del sujeto.

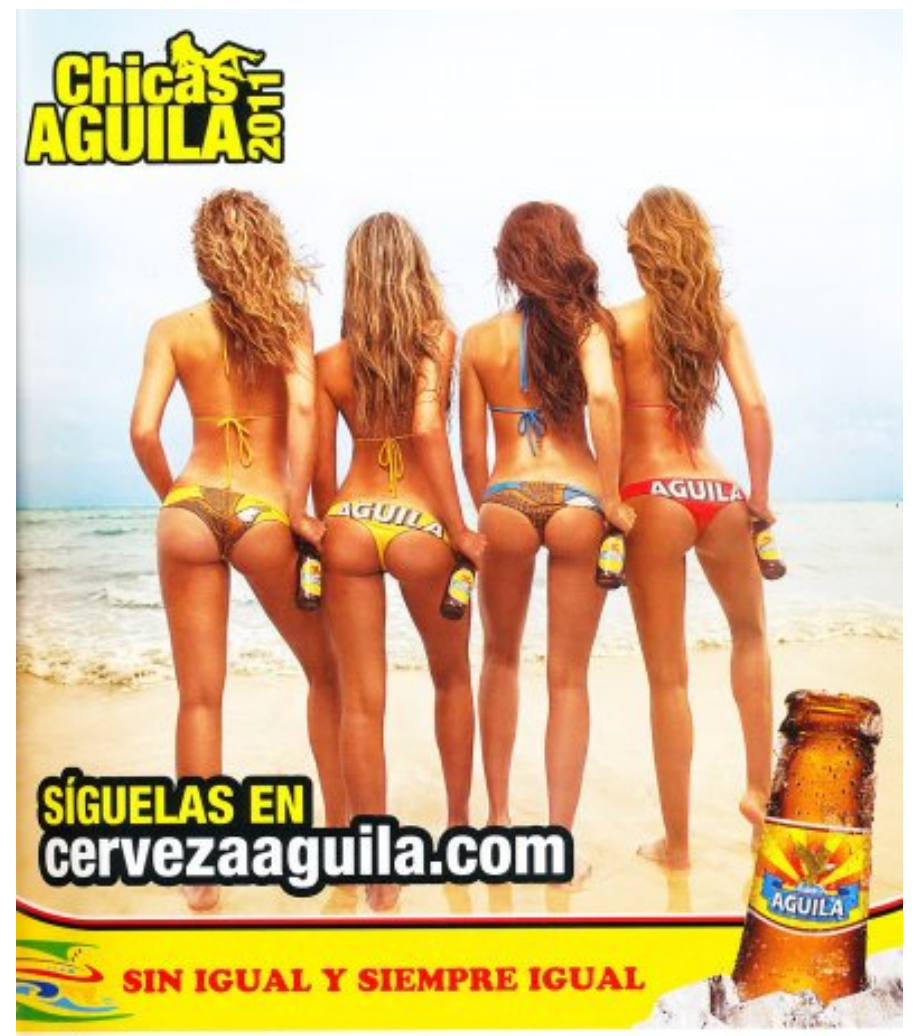

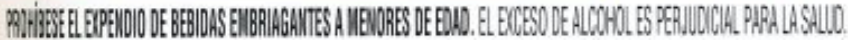

Figura 5. Publicidad. “Chicas Águila con botella”, Cerveza Águila. "Fuente: http://www.colarte.com/colarte/foto.asp?idfoto=294580"

En los inicios de la campaña se promovió el eslogan Sabor, cuerpo y color, en un doble sentido que remitía a las cualidades gastronómicas ofertadas en la cerveza, y la analogía con las características raciales de las modelos. El sabor, entendido como calidad gustativa de la bebida, es análogo a las calidades rítmicas o cadenciosas de las mujeres ante la música. El cuerpo que un catador encontraría en el buqué de la cerveza, es el símil con los cuerpos perfectos de las modelos, y el color, que en el objetivo práctico del producto se quedaría en el dorado del líquido, está referido a la rubia, la morena o la latina. Constatamos que la estrategia publicitaria resume, a través de la metáfora, una forma de cosificar, volver objeto, poner al mismo nivel del producto -la cerveza-a la mujer. 
Toloza Hernández, José Germán

Las Chicas Águila. El uso sexista de la mujer en la publicidad colombiana

IV Congreso INTERNACIONAL DE INVESTIGACIÓN EN ARTES VISUALES ANIAV 2019

IMAGEN [N] VISIBLE]

http://dx.doi.org/10.4995/ANIAV.2019.9019

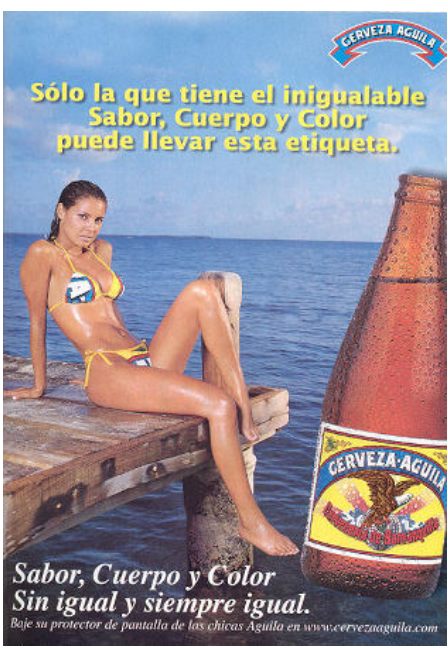

Figura 6. Afiche. "Sabor, cuerpo y color", Cerveza Águila. "Fuente: http://www.colarte.com/colarte/foto.asp?idfoto=162924"

Fútbol, mujeres y Patria. Colombia es pasión

En una de sus reflexiones, Yolanda Domínguez (2017) nos invita a indagar por el carácter político en el uso de las imágenes. La aparente inocencia que presentan ciertas imágenes es peligrosa en tanto que la superficie de lo estético y la gracia de gestos anulan cualquier posibilidad crítica en el contexto y en relación con las intenciones patriarcales, capitalistas y políticas.

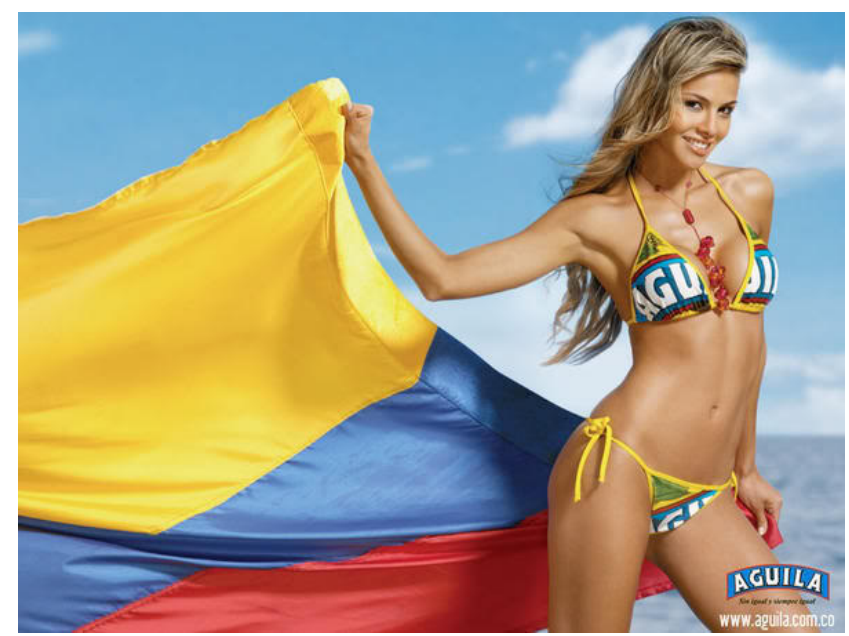

Figura 7. Publicidad. “Chica Águila con bandera de Colombia”, Cerveza Águila. "Fuente: https://www.taringa.net/+imagenes/las-chicas-aguila-colombia_i3efr”

Abordemos, en un caso, la relación entre la publicidad y los intereses de imagen de un gobierno, en el que los estereotipos femeninos pueden haber cumplido un uso sustancial. Colombia tiene una historia cruzada por la violencia partidista desde los años 40 , reforzada con el surgimiento de la guerrilla, los enfrentamientos con el Ejército Nacional y la posterior aparición de grupos paramilitares y carteles del narcotráfico. Los acontecimientos sangrientos han sido constantes por más de cincuenta años, durante los cuales la población civil ha sido la principal víctima del conflicto. Se trata, en su mayoría, de campesinos o habitantes de pequeños centros urbanos, desterrados de sus tierras y abocados a formar una nueva clase social urbana -miserable por demás- de desplazados de la violencia.

En este escenario, los gobiernos no han dudado de la efectividad de usar cortinas de humo para encubrir el dolor y conjurar cualquier intento de sublevación por parte de la comunidad. Los bálsamos para el conformismo son las estrategias populistas en las que emerge todo tipo de alegría efímera o de señales de felicidad ante el triunfo ajeno, y en ese terreno están la televisión, los reinados de belleza y la selección masculina de fútbol.

La heráldica y los símbolos de identificación son esenciales para transmitir mensajes y manipular la respuesta frente a determinadas conductas. Los colores en Las Chicas Águila corresponden al tricolor colombiano. Ese punto de encuentro puede hallarse en una idea 
Toloza Hernández, José Germán

Las Chicas Águila. El uso sexista de la mujer en la publicidad colombiana

IV Congreso INTERNACIONAL DE INVESTIGACIÓN EN ARTES VISUALES ANIAV 2019 IMAGEN [N] VISIBLE]

http://dx.doi.org/10.4995/ANIAV.2019.9019

que se ha intentado vender a la sociedad colombiana en los últimos veinte años con el pretexto de ofrecer una imagen positiva del país ante el mundo, y es que los colombianos somos pasión y uno de los países más felices del mundo.

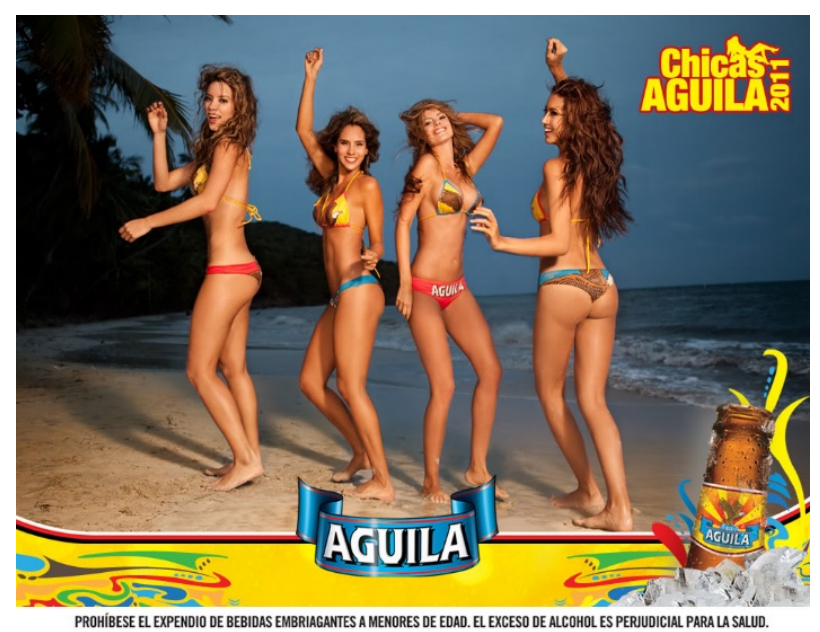

Figura 8. Publicidad. "Mujeres celebrando en la playa", Cervecería Bavaria. "Fuente: https://www.taringa.net/+imagenes/las-chicas-aguila-parte-2-bellezacolombiana-parte-4 13lqp2"

Mujer, pasión, corazón, intensidad, felicidad, son conceptos que bien pueden ser leídos en las imágenes de Las Chicas Águila desde una figuración hiperrealista. Esa felicidad en escenarios paradisiacos con mujeres perfectas y alegres, no es nuestra, pero nos es prometida en imágenes y videos publicitarios, nos gusta, nos convence y nos aliena.

\section{Musas del mar}

En los escenarios donde se exhiben Las Chicas Águila hay una reinterpretación de la pasarela bajo la edición meticulosa de paisajes naturales y artificiales, donde se exponen estereotipos idealizados que nada tienen que ver con la realidad de las personas, y menos como símbolos de la belleza y la alegría de un país. Lo que hay de fondo es proyectar idealizaciones de belleza tropical, con un espectro amplio que dé cabida a diferentes estereotipos de mujer, variedad de musas del mar para todos los gustos.

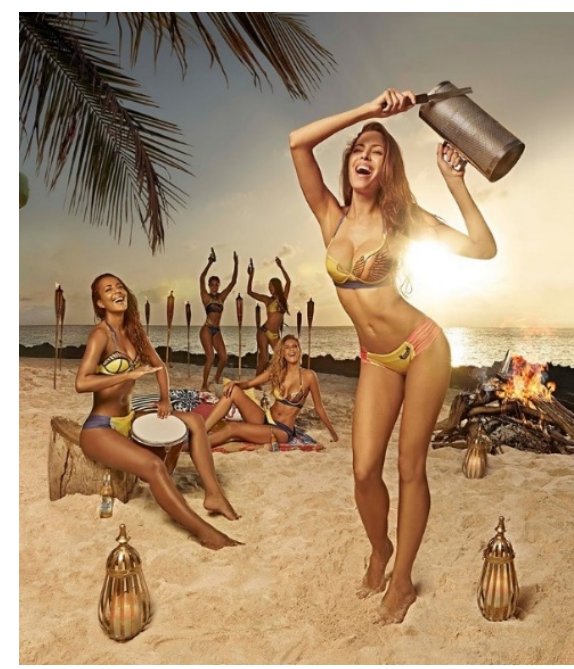

Figura 9. Publicidad. "Chicas Águila disfrutando en la playa”, Cervecería Águila, 2016. "Fuente: https://www.behance.net/gallery/34694117/Calendario-ChicasAguila-2016"

Las Chicas Águila tienen un enfoque estereotipado de belleza tropical o musas del mar que ha sido utilizado en otras latitudes y ámbitos. Una mujer de "belleza tropical" en los estereotipos del mercado del espectáculo hace referencia a una tipología que combina rasgos afines al trajinado exotismo del trópico, pieles bronceadas, caderas cadenciosas al ritmo de la música, cabelleras onduladas y exuberantes, cuerpos de curvas y formas voluptuosas y una notoria predisposición a la alegría y la celebración a la rumba. 
Toloza Hernández, José Germán

Las Chicas Águila. El uso sexista de la mujer en la publicidad colombiana

IV Congreso INTERNACIONAL DE INVESTIGACIÓN EN ARTES VISUALES ANIAV 2019

IMAGEN [N] VISIBLE]

http://dx.doi.org/10.4995/ANIAV.2019.9019

El sentido político de inclusión es algo que han intentado el cine, las telenovelas, los telediarios y la publicidad, al considerar en sus filas una representante de las etnias afrocaribes e indígenas. Esta es una política que ha seguido el concurso de Las Chicas Águila. Podemos suponer que toda versión de espectáculo que ofrezca en escena varios actores o varias actrices, pensará en su ecuación simple ofrecer variedad de mujeres como una forma de conquistar un mayor espectro de público.

\section{Un cambio repentino}

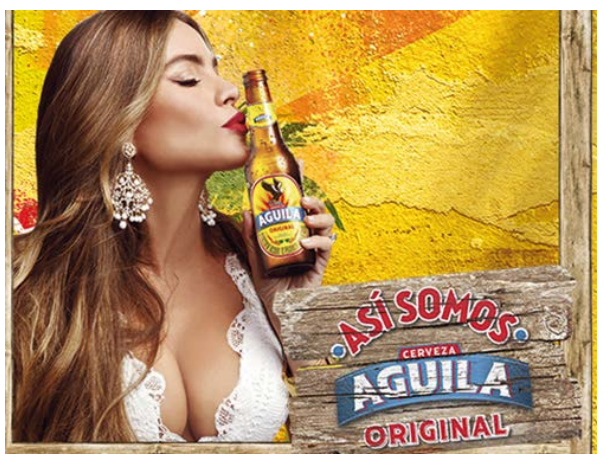

Figura 10. Publicidad. "La modelo y actriz Sofía Vergara", Cervecería Águila, 2006. "Fuente: https://www.colombiamegusta.com/la-cerveza-aguila-preciomundial-rusia-2018/"

En el año 2006, repentinamente Las Chicas Águila desaparecen del escenario y son reemplazadas por la famosa modelo y actriz colombiana Sofía Vergara, quien aparece solitaria promocionando una nueva campaña llamada "Sofía llegó a destapar la originalidad". El nuevo concepto la muestra en un vestido blanco con mucho encaje y bordado, con un gran escote, mientras destapa una botella de cerveza. De la informalidad de la chica en bikini se pasa a la elegancia del vestido blanco de fiesta.

El escenario sigue siendo la playa, más concretamente los chiringuitos playeros, y acompañan a la modelo frases como "El destape de Sofía", "Que nuestra reina los cumpla feliz muy feliz", "Que suene lo de acá" y "Así somos", entre otras. Podemos observar que hay un cambio sustancial, aunque sigue apareciendo la mujer como objeto del deseo junto a la botella. Una de las imágenes muestra a la modelo besando la botella de cerveza, quizás manteniendo esa idea de la mujer a que se refiere Campos (2016).

No sabemos aún si Las Chicas Águila vuelvan a aparecer, o si el cambio se debe a que la industria publicitaria y la empresa tomaron conciencia sobre las connotaciones machistas, utilitaristas y estereotipadas de la mujer, en cuyo caso estaríamos asistiendo a un interesante momento de transformación de actitudes que propician la violencia de género.

\section{CONCLUSIONES}

La campaña de Las Chicas Águila es un ejemplo de estrategia publicitaria profesionalmente diseñada para vender un estilo de vida, en el cual se ofrece al espectador la posibilidad de disfrutar viendo a mujeres erotizadas y complacientes en bikini y en paisajes paradisiacos, en actitudes de festejo y celebración, cuyo producto objeto (la botella o la lata de cerveza), actúa como fetiche que culmina o completa el deseo erótico.

Aprovechando la indiscutible belleza de estas mujeres, las bondades artísticas de la fotografía y las tecnologías digitales para el diseño, la campaña se enfoca en aprovechar a la mujer como objeto de deseo. Utiliza los estereotipos femeninos relacionados con la juventud, la belleza y la alegría, además de las tipologías raciales, para vender cerveza. La campaña usa a la mujer al nivel de objeto, normalizando su imagen para ser mirada y consumida, perpetuando la acción como experiencia bella y común en el cotidiano.

La mujer, a través de su figura sexualizada en público, es llevada al nivel de un adorno para la venta de un producto. Esto se convierte en una forma más de violencia de género revestida a través de la gratificación que, se supone, ofrece el dinero y la fama de ser Chica Águila, como estereotipo de éxito y belleza. El éxito de la estrategia, bajo la figura del reinado de belleza, proyecta expectativas en las mujeres jóvenes, educando para la normalización y el utilitarismo de la mujer como objeto.

La articulación de la campaña publicitaria basada en el culto al cuerpo de la mujer sexualizada, con otras áreas como la politización de la cultura popular, a expensas del amor patrio y la afición al fútbol, homogenizan y banalizan la identidad de un país, y de paso cultivan 
la insensibilidad frente a la sexualización de las jóvenes para el mercado. Esto supone un aprovechamiento, por parte de los gobiernos y la empresa, de la escenificación del cuerpo de la mujer como espectáculo, generando cortinas de humo distractoras frente a los verdaderos problemas de la sociedad.

A la fecha de hoy no hay políticas de control significativas que tipifiquen las estrategias publicitarias en el uso de la imagen, que identifiquen sus métodos con los estereotipos que vulneran y violentan a la mujer y que, por el contrario, normalizan y multiplican comportamientos machistas hacia ella. Por ello, es importante generar reflexiones en torno a estos fenómenos que inviten o permitan una lectura crítica de las situaciones por parte de los espectadores, replanteándose el respeto y la dignidad de la mujer, para construir nuevas generaciones de publicistas, actores implicados y públicos alfabetizados y críticos frente a la lectura de las imágenes.

\section{REFERENCIAS}

Campos, V. (2016). El fetiche: un resplandor que ciega en la magna mujer de la publicidad. Brasil: UNIFACS, Universidad Salvador.

Domínguez, Y. (2017, octubre). Revelando estereotipos que nos representan. Ver video en TEDxMadrid [Video YouTube]. Recuperado 9 de enero de 2017, de https://www.youtube.com/watch?v=H1C-vG4yBMI

Peninou, G. (1976). Semiótica de la publicidad. Barcelona: Gustavo Gili Editores.

Puelles, L. (2009). Ilusiones de Eros: tensiones del cuerpo y las imágenes. Arte y parte, 84, 16-35.

Rodríguez, N. (2009). Las mujeres y un pintor. La imagen de la femme fatale y la mujer española de principios del siglo XX (tesis de maestría). Madrid: Universidad Complutense de Madrid. 